\title{
THE INFLUENCE OF ANTIBIOTIC TREATMENT ON RESISTANCE PATTERNS OF COLIFORM BACILLI IN CHILDHOOD URINARY- TRACT INFECTION
}

\author{
R. N. Grüneberg* and Elizabeth J. Shaw $\ddagger$ \\ Department of Bacteriology*, University College Hospital, London WC1 and \\ $\dagger$ Royal Postgraduate Medical School, London W12
}

COLIFORM bacilli (" coliforms") that carry resistance-transfer (R) factors form part of the normal bowel flora of children and adults (Datta, 1969; Gillespie et al., 1971); such strains, whether acquired in hospital or in the community, may cause infection (Brumfitt et al., 1971; Anderson, Datta and Shaw, 1972; Shaw et al., 1973a; Shaw, Clark and Anderson, $1973 \mathrm{~b}$ ). In reports of the frequency of carriage of $\mathrm{R}+$ coliforms in the bowel of normal persons from two geographical areas (Dublin and Bristol), it was found that this was much higher in children than adults (Moorhouse, 1969; Linton, Richmond and Gillespie, 1971).

We investigated the frequency of $\mathbf{R}+$ coliforms as causes of urinary-tract infection (UTI) in children, determined the carriage rate of $\mathbf{R}+$ coliforms in the bowel of children resident in the London area and correlated the antibiotic-resistance pattern of the urinary pathogen with that of coliforms from the patient's own bowel flora.

\section{MATERIALS AND METHODS}

Organisms isolated from children aged 5 months to 16 years attending an out-patient clinic for urinary-tract infections at University College Hospital during 1970-71 were examined. The organism that caused each episode of urinary-tract infection was examined together with 10 lactose-fermenting gram-negative organisms isolated from a specimen of faeces taken within 3 days of the urine specimen. All organisms were kept in nutrient agar stabs or on dorset's egg slopes until examined for drug resistance. The clinic, the selection and treatment of the patients under study, and the method of collection of urine specimens are described elsewhere (Smellie et al., 1964; Normand and Smellie, 1965). Any antimicrobial agents that were being given at the time of onset of the infection were noted. Patients who had been in hospital during the preceding 6 months were excluded.

The resistance of each isolate to ampicillin, streptomycin, tetracycline, chloramphenicol, kanamycin, sulphadimidine, gentamicin, trimethoprim and nalidixic acid was determined (for methods, see Shaw et al., 1973a and $b$ ). Strains that were resistant to any antibacterial agent were incubated in mixed culture with the genetically labelled recipient Escherichia coli $\mathrm{K} 12$, and examined for transferable resistance (for methods, see Datta, 1968).

\section{RESULTS}

Frequency of $R+$ coliforms as causes of urinary-tract infections in children who were not receiving chemotherapy

We studied 40 episodes of urinary-tract infection in 35 children who were not receiving antibiotics at the time of onset of the infection; cultures of the urine yielded Escherichia coli in 37 episodes, Klebsiella sp. in two episodes, and Enterobacter cloacae in one episode. The antibiotic-resistance patterns of the isolates are shown in table I. Ten of the E. coli

Received 21 Nov. 1974; accepted 7 Oct. 1975.

‡ Present address: Bacteriology Department, St Bartholomew's Hospital, London EC1.

J. MED. MICROBIOL.--VOL. 9 (1976) 
strains $(27 \%)$ and both of the Klebsiella strains were resistant to at least one antibiotic; the frequency of resistant coliforms was thus $30 \%$. Six of the 10 resistant strains of $E$. coli could transfer resistance to $E$. coli $\mathrm{K} 12$ whereas the two strains of Klebsiella could not.

\section{Effect of oral chemoprophylaxis on the frequency of $R+$ coliforms in the bowel flora of children}

Some of the children attending the clinic had been receiving either sulphonamide or nitrofurantoin for long-term prophylaxis of urinary-tract infection; the faecal flora of 65 of these children was compared with that of 19 of the children who were not receiving chemoprophylaxis (table II). The coliform flora was considered to be "sensitive" if none of the 10 colonies examined was resistant to any antibacterial agent, and "predominantly resistant" if $\geqslant 5$ colonies were resistant. Of the 19 untreated children, $12(63 \%)$ had a sensitive and $3(16 \%)$ a predominantly resistant flora. The corresponding figures for 19

TABLE I

Resistance patterns of organisms causing urinary-tract infection in children*

\begin{tabular}{|c|c|c|}
\hline Organism & Resistance pattern & Number of strains \\
\hline $\begin{array}{l}\text { Escherichia coli } \\
E . \text { coli } \\
E . \text { coli } \\
E . \text { coli } \\
\text { E. coli } \\
\text { E. coli } \\
\text { E. coli } \\
\text { E. coli } \\
\text { Klebsiella } \\
\text { Klebsiella } \\
\text { Enterobacter } \\
\text { cloacae }\end{array}$ & $\begin{array}{l}\text { Fully sensitive } \\
\text { T } \\
\text { SSu } \\
\text { AS } \\
\text { STSu } \\
\text { AST } \\
\text { ATC } \\
\text { ASTCSu } \\
\text { A } \\
\text { AST } \\
\text { Fully sensitive }\end{array}$ & $\begin{array}{r}27 \\
3 \\
2 \\
1 \\
1 \\
1 \\
1 \\
1 \\
1 \\
1 \\
1\end{array}$ \\
\hline
\end{tabular}

$\mathrm{A}=$ ampicillin $; \mathrm{S}=$ streptomycin $; \mathrm{T}=$ tetracycline $; \mathrm{C}=$ chloramphenicol; $\mathrm{Su}=$ sulphonamide.

* Not in receipt of antibacterial agents at onset; not in hospital during the previous 6 months.

TABLE II

Effect of oral sulphonamide and nitrofurantoin on the resistance patterns of bowel coliforms* in children

\begin{tabular}{|c|c|c|c|c|}
\hline \multirow{2}{*}{$\begin{array}{l}\text { Antibacterial agent } \\
\text { administered }\end{array}$} & \multirow{2}{*}{$\begin{array}{c}\text { Number of patients } \\
\text { examined }\end{array}$} & \multicolumn{3}{|c|}{ Number (and percentage) of patients with } \\
\hline & & sensitive flora $\dagger$ & $\begin{array}{l}\text { predominantly } \\
\text { sensitive flora } \ddagger\end{array}$ & $\begin{array}{l}\text { predominantly } \\
\text { resistant flora } \S\end{array}$ \\
\hline $\begin{array}{l}\text { None } \\
\text { Sulphonamide } \\
\text { Nitrofurantoin }\end{array}$ & $\begin{array}{l}19 \\
46 \\
19\end{array}$ & $\begin{array}{r}12(63) \\
13(28) \\
8(42)\end{array}$ & $\begin{array}{l}4(21) \\
7(15) \\
4(21)\end{array}$ & $\begin{array}{r}3(16) \\
26(57) \\
7(37)\end{array}$ \\
\hline
\end{tabular}

* Ten colonies examined from each patient's faeces.

+ No colonies resistant.

* One to four colonies resistant to one or more antibacterial agent.

$\$$ Five or more colonies resistant to one or more antibacterial agent. 
children receiving nitrofurantoin were $8(42 \%)$ sensitive and $7(37 \%)$ predominantly resistant; and for 46 children receiving sulphonamides $13(28 \%)$ sensitive and $26(57 \%)$ predominantly resistant. Sixty of the resistant faecal strains were selected at random, and transfer of resistance to $E$. coli $\mathrm{K} 12$ was demonstrated after growth in mixed culture from $30(50 \%)$ of the strains tested.

\section{Correlation of resistance pattern of infecting organism with that of the faecal flora}

Both faeces and urine were obtained from 29 patients suffering from urinary-tract infection (table III). Coliforms resistant to at least one drug were isolated from the urine in six of the eight patients in whom the majority of faecal flora was resistant but from only two of the 21 patients with a sensitive or predominantly sensitive flora.

\section{Discussion}

Some $30 \%$ of the coliform bacilli isolated from the urine in this series of children with urinary-tract infection were resistant to at least one antibacterial drug, a percentage not significantly different from those observed during the same years by Shaw et al. (1973a and $b$ ) in symptomatic adults and in pregnant women with asymptomatic infection. The frequency of demonstrable transfer of antibiotic resistance by $E$. coli strains from infections in children and adults was also similar. Most of the resistant strains from the children were resistant to more than one antibacterial agent, but only one strain was resistant to three, and in every case a suitable agent was available for treatment.

The faecal flora of most of the children who were not receiving an oral antibacterial agent was sensitive or predominantly sensitive; in only three of 19 children $(16 \%)$ did resistant coliforms predominate; comparable percentages for adults are $23 \%$ (Datta et al., 1971) and $24 \%$ (Shaw et al., 1973c). Of children who were receiving antimicrobial agents, one-half had a predominantly resistant faecal flora, but differences were apparent between children receiving different drugs. In children taking sulphonamide, $57 \%$ had a predominantly antibiotic-resistant intestinal flora in comparison with only $37 \%$ in those taking nitrofurantoin. This indicates that sulphonamide therapy has a similar effect on the bowel flora of children and adults (Datta et al., 1971).

The prevalence of resistant coliforms in the urine parallels that in the rectal flora in children as in adults (Brumfitt et al., 1971). This tends to confirm the view that strains of $E$. coli that cause urinary-tract infections are those prevalent in the bowel rather than strains having some special pathogenicity (Grüneberg, Leigh and Brumfitt, 1968). Moreover, the presence or absence of an $\mathrm{R}$ factor does not affect the likelihood that a particular strain will cause urinary infection.

TABLE III

Correlation between the presence of resistant coliforms* in urine and in faeces of children with urinary-tract infection

\begin{tabular}{c|ccc}
\hline $\begin{array}{c}\text { Proportion of faecal coliforms } \\
\text { that were resistant }\end{array}$ & $\begin{array}{c}\text { Number of patients } \\
\text { examined }\end{array}$ & \multicolumn{2}{c}{$\begin{array}{c}\text { Number of patients with urinary } \\
\text { coliforms that were }\end{array}$} \\
\hline $10-40 \%$ & 16 & 15 & resistant \\
$>50 \%$ & 5 & 4 & 1 \\
\hline
\end{tabular}

* See footnotes to table II. 
Our results do not agree with those of Moorhouse in Dublin (1969) and Linton and his colleagues in Bristol (1971), who found that the carriage of $\mathbf{R}+$ bacteria in children was much more frequent than in adults. However, our children showed a much greater age range ( 5 months to 16 years), those in Bristol all being under 5 years and the Irish children under 2 years of age. It is now well established, and confirmed in this study, that previous chemotherapy alters the antibiotic-resistance pattern of the bowel flora (Datta et al., 1971; Grüneberg, Smellie and Leakey 1973; Shaw et al., 1973c). In adults this change is transitory and the flora reverts to its pre-treatment state after 5 weeks (Datta et al. 1971). It has also been shown that the distribution of $O$ serotypes of $E$. coli varies from place to place (Grüneberg and Bettelheim, 1969); this may also be true of R factors.

We have previously reported a much higher proportion of faecal organisms resistant to antibiotics in children who are receiving sulphonamides or ampicillin than in children who are receiving nitrofurantoin, cotrimoxazole or nalidixic acid (Grüneberg et al., 1973), and that the recurrence rate of urinary-tract infection is much higher in children receiving ampicillin, sulphonamide or tetracycline than in those receiving nitrofurantoin. Our present observation, that the majority of the resistances in both urinary and faecal coliforms are R-factor-mediated, suggests the following approach to the choice of antimicrobial agents for the prophylaxis of urinary-tract infection in children. Antibiotics to which resistance is $\mathrm{R}$-factor-mediated (sulphonamide, ampicillin and tetracycline) produce a highly resistant faecal flora from which the organisms causing reinfection of the urinary tract are derived. Therefore, these antibiotics should not be used for prophylaxis. On the other hand, antimicrobial agents to which resistance is not R-factor-mediated (nitrofurantoin and nalidixic acid) produce only slight changes in the antibiotic resistance of the faecal flora, so preserving the value of these drugs for prophylaxis. The effect of cotrimoxazole would be expected to resemble closely that seen with nitrofurantoin and nalidixic acid only so long as R-factor-mediated trimethoprim resistance remains rare. Further studies to test this theory and the relative efficacy of different antimicrobial drugs for the prophylaxis of urinary-tract infection in children are in progress.

\section{SUMmARY}

The occurrence of coliform bacilli carrying resistance-transfer factors ( $\mathrm{R}$ factors) in children was studied. The frequency of $\mathrm{R}+$ coliform bacilli as causes of urinary-tract infection acquired outside hospital was found to be similar to that in adults from the same geographical area and in the same years. The frequency of $\mathrm{R}+$ coliform bacilli in the faeces in our children was also similar to that in the adult population, and oral chemotherapy produced similar changes in the faecal flora.

We are grateful to Dr Jean Smellie for permission to study patients under her care, to Dr Naomi Datta for advice, to Mrs Ann Leakey and Miss Gillian Aaronson for technical assistance and to the Medical Research Council, Beecham Laboratories and Roche Products Ltd for support of different aspects of this work.

\section{REFERENCES}

Anderson, F. M., Datta, N. and Shaw, E. J. 1972. R factors in hospital infection. Br. med. J., 3, 82.

Brumfitt, W., Faiers, M. C., Reeves, D. S. and DatTa, N. 1971. Antibiotic-resistant Escherichia coli causing urinary-tract infection in general practice; relation to faecal flora. Lancet, 1, 315.

DatTA, N. 1968. Acquisition of antibiotic resistance by bacteria. In Recent advances in clinical pathology, edited by S. C. Dyke, London, p. 43.

DAtTA, N. 1969. Drug resistance and $R$ factors in the bowel bacteria of London patients before and after admission to hospital. Br. med. J., 2, 407. 
Datta, N., Faiers, M. C., Reeves, D. S., Brumfitt, W., Ørskov, F. and Ørskov, I. 1971. $\mathrm{R}$ factors in Escherichia coli in faeces after oral chemotherapy in general practice. Lancet, 1, 312.

Gillespie, W. A., Lee, P. A., Linton, K. B. AND Rowland, A. J. 1971. Antibiotic resistance of coliform bacilli in urinary infection acquired by women outside hospital. A 12 year survey. Lancet, 2, 675.

GrüNEBERG, R. N., AND Bettelheim, K. A. 1969. Geographical variation in serological types of urinary Escherichia coli. J. med. Microbiol., 2, 219.

GrüNeberg, R. N., LeIGH, D. A. AND BRUMFITT, W. 1968. Escherichia coli serotypes in urinary tract infection: studies in domiciliary, antenatal and hospital practice. In Urinary tract infection, edited by F. O'Grady and W. Brumfitt, London, p. 68.

Grüneberg, R. N., Smellie, J. M. and Leakey, A. 1973. Changes in the antibiotic sensitivities of faecal organisms in response to treatment in children with urinary tract infection. In Urinary tract infection, edited by W. Brumfitt, and A. W. Asscher, London, p. 131.

Linton, K. B., Richmond, M. H. AND Gillespie, W. A. 1971. Influence of employment with livestock on antibiotic resistant $E$. coli in the faeces of healthy people. J. clin. Path., 24, 767.

MoORHOUSE, E. C. 1969. Transferable drug resistance in enterobacteria isolated from urban infants. Br. med. J., 2, 405.

Normand, I. C. S. ANd Smellie, J. M. 1965. Prolonged maintenance chemotherapy in the management of urinary infection in childhood. Br. med. J., 1, 1023.

Shaw, E. J., Pursell, R. E., Datta, N. AND Brumfitt, W., 1973a. R factors in Enterobacteriaceae causing urinary tract infection in general practice in 1962-63 and 1968-69. J. med. Microbiol., 6, 451 .

Shaw, E., J. Clark, A. D. AND Anderson, F. M. 1973b. R factors in Enterobacteriaceae causing asymptomatic bacteriuria of pregnancy. J. med. Microbiol., 6, 455.

Shaw, E. J., Datta, N., Jones, G., MarR, F. M. and Froud, W. J. B. 1973c. Effect of stay in hospital and oral chemotherapy on the antibiotic sensitivity of bowel coliforms. J. Hyg., Camb., 71, 529.

Smellie, J. M., Hodson, C. J., Edwards, D. And Normand, I. C. S. 1964 . Clinical and radiological features of urinary infection in childhood. Br. med.J., 2, 1222. 